\title{
Royseux: a palaeobiodiversity hotspot in the Late Viséan (Carboniferous) of Belgium
}

\author{
JuLIEN DENAYER ${ }^{1 *}$, MARKus ARETZ², EdOUARD POTY ${ }^{1}$, BERNARd MOTTEQUIN ${ }^{3}$
}

${ }^{1}$ Evolution and Diversity Dynamics Lab, Université de Liège, Allée du Six-Août B18, Sart Tilman, B-4000 Liège, Belgium, e-mails : julien.denayer@ulg.ac.be; e.poty@ulg.ac.be.

${ }^{2}$ Géosciences Environnement Toulouse (OMP), Université de Toulouse, (UPS), Av Edouard Belin 14, F-31400 Toulouse, France, email: markus.aretz@get.omp.eu.

${ }^{3}$ O.D. Earth and History of Life, Royal Belgian Institute of Natural Sciences, rue Vautier 29, B-1000 Brussels, Belgium, e-mail: bmottequin@naturalsciences.be.

* corresponding author

ABSTRACT. Biodiversity hotspots are defined as areas of unusually high biological diversity. This definition is less clear for palaeohotspots but the Royseux locality in Southern Belgium is interpreted as such a site because of the large number of coral species that co-occur within a small area and short time interval. Forty-one species (29 genera) of rugose, tabulate and heterocorallia corals are known within a $6 \mathrm{~m}$-thick $4^{\text {th }}$ order parasequence $(100 \mathrm{kyr})$. These numbers increase to 50 species in 30 genera if the entire succession is considered. Consequently, Royseux is regarded as the richest site for late Viséan coral diversity on a global scale. Comparison with other sites from Spain, Morocco, the British Isles, and eastern Australia confirms this view. The diversity of brachiopods (at least 18 species within 16 genera) and other invertebrates is also assessed. The great palaeobiodiversity is tentatively explained by the interplay of several global and local causes, including high late Viséan biodiversity at the global scale associated with tectonically and sedimentarydriven micro-environment differentiation. Conversely, the Royseux locality has yielded few endemic taxa.

KEYWORDS: biodiversity, disparity, hotspot, endemism, corals, brachiopods, reef, Carboniferous.

\section{Introduction}

Quantifying biodiversity has become a major concern, not only for modern ecology and nature conservation, but also in the fossil record, where the aim is understanding the effects of global changes on the diversity of past life. During the last decade the palaeontological literature dealing with changes in biodiversity over large time scales (periods, stages) has increased significantly. Unfortunately, most papers failed the difficult task of pinpointing the origin of biodiversity: why so many taxa occur(ed) in a particular area at a particular time, why is the diversity not globally distributed, and why do many taxa occur only in localised areas?

Biodiversity hotspots are sites or areas with an unusually high numbers of co-occurring species (Myers, 1988). Presentday biodiversity hotspots are defined as biogeographic areas where the density of co-occurring species is extraordinarily high (Marchese, 2015) and/or as areas with a high density of endemic species, most of which are currently suffering habitat loss (Myers et al., 2000). Although this definition is easily applicable to present biodiversity, it is difficult to recognise ancient biodiversity hotspots and few examples have been recorded (e.g. origin and shift of modern marine tropical hotspots of the Indo-Australian Archipelago: Renema et al., 2008; mollusc palaeo-hotspot in the Lutetian of the Paris Basin: Merle, 2008; endemic crinozoan hotspots in the Pennsylvanian of North America: Waters \& Webster, 2012). Nevertheless, in the case of fossil assemblages, the time scale enters into the equation because each assemblage represents a certain amount of time. To understand ancient diversity hotspots it is necessary to focus on as narrow a time interval as possible in order to avoid temporal dilution of the signal due to the shift of environments and thus ecosystems through time. The number of taxa (species, genera, etc.), irrespective of their phylogenetic relationship, is commonly used to denote total diversity, but it is strongly biased by the quality of the geological record, taphonomy and sampling effort, and tabulation methods have been abundantly criticised (see discussion in Cecca, 2002; Brown \& Lomolino, 2010). Hence, a second condition for a well-defined hotspot is a fossiliferous site characterised by well-preserved fossils, well-established geological context and sampling as comprehensive as possible. However, temporal issue in biodiversity can be circumvented through the use of normalised diversity (standing diversity rather than total diversity, see Webb et al., 1997, for example)

The Royseux locality in southern Belgium (Fig. 1) is such a site. The considered time slice corresponds roughly to a $4^{\text {th }}$ order parasequence $(100 \mathrm{kyr})$; its geological and palaeoenvironmental settings are well understood; the preservation is generally excellent; and the faunal record results from more than 40 years of sampling.
Figure 1. Locality map of the Royseux sections in the Dinant Synclinorium (green areas represent the Lower Carboniferous outcrop zones) with a close-up view showing the position of sections I, II, IIIA, IIIB and borehole IIIC. Legend: ESN: Esneux Formation (Fm), SVP: Souverain-Pré Fm, ME: Montfort-Evieux Fm (Famennian), LIV: Lives Fm, SEI: Seilles Mbr, POI: Poilvache Mbr (both within Grands-Malades Fm), ANH: Anhée Fm. General map after Poty et al. (2006), geological map after Barchy \& Marion (in press) and Mottequin \& Marion (in press).

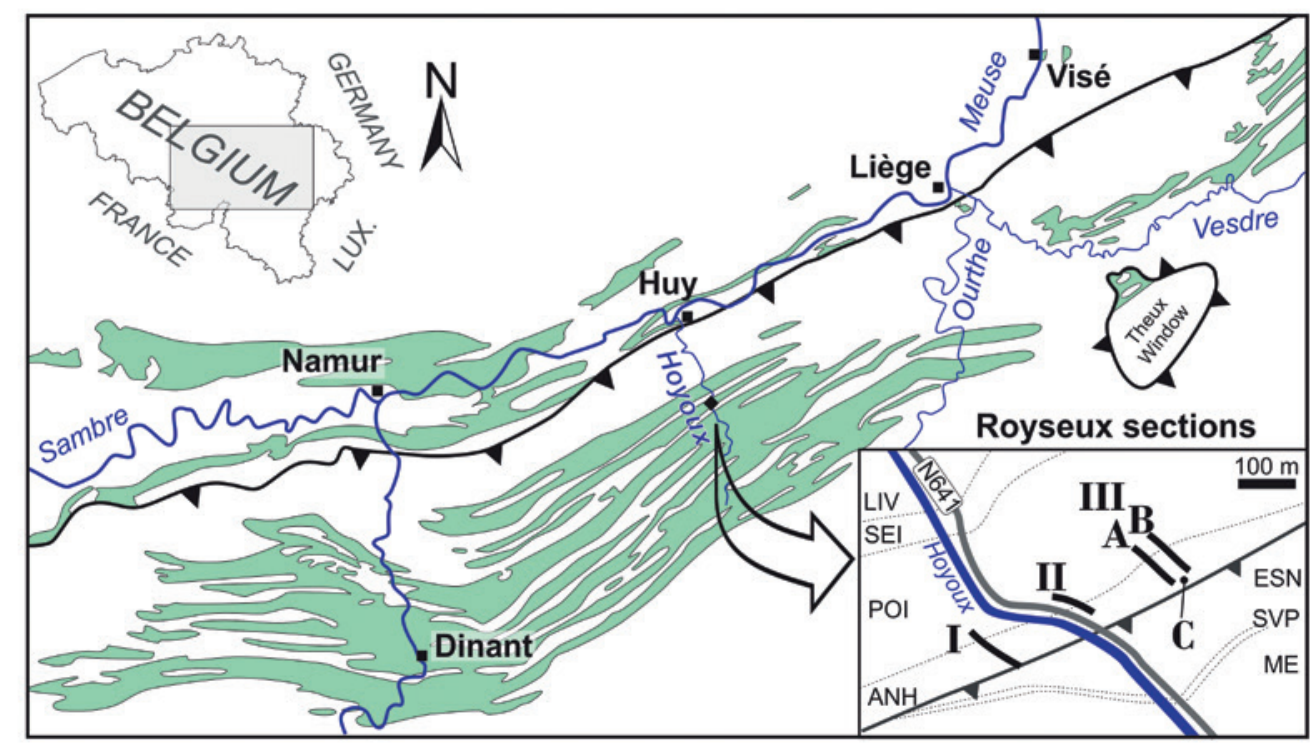




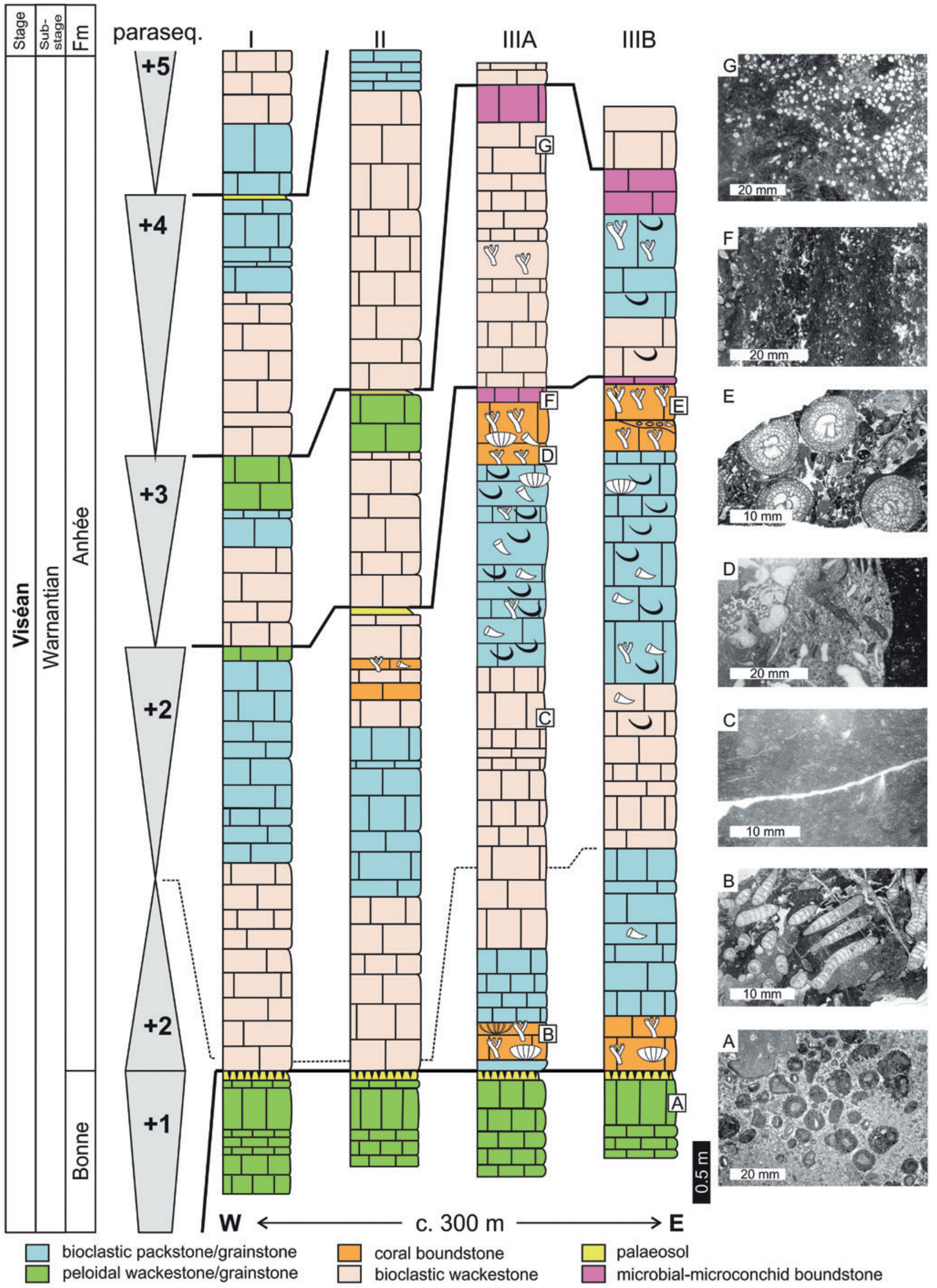

Figure 2. Logs of the Royseux sections (I, II, IIIA and IIIB, see Fig. 1 for location) with indication of the parasequences ( +1 to +5$)$ and the main facies. A: peloidal packstone-grainstone with centimetric oncoids. B: Siphonodendron junceum bafflestone. C: fine-grained bioturbed bioclastic packstone. D: coarse bioclastic rudstone with fragments of gigantoproductid, rugose corals and pelmatozoans. E. Siphonodendron martini bafflestone with a bioclastic grainstone matrix. F: microbial-microconchid boundstone. G: Saccaminopsis packstone. Modified from Poty et al. (2011). 


\begin{tabular}{|c|c|c|c|c|c|c|c|c|c|}
\hline & $\begin{array}{l}\text { global } \\
\text { abundance }\end{array}$ & $\begin{array}{l}\text { first } \\
\text { biostrome }\end{array}$ & $\begin{array}{l}\text { bioclastic } \\
\text { facies of } \\
\text { paraseq. } \\
+2\end{array}$ & $\begin{array}{l}\text { gigantiprodu- } \\
\text { ctines beds of } \\
\text { paraseq. }+2\end{array}$ & $\begin{array}{l}\text { second } \\
\text { biostrome }\end{array}$ & $\begin{array}{l}\text { conglomerate } \\
\text { horizon }\end{array}$ & $\begin{array}{l}\text { complete } \\
\text { paraseq. } \\
+2\end{array}$ & $\begin{array}{l}\text { paraseq. } \\
+3\end{array}$ & $\begin{array}{l}\text { upper } \\
\text { paraseq. } \\
\text { (RC8) }\end{array}$ \\
\hline Amygdalophyllum sp. & $*$ & & & & & $*$ & $*$ & & \\
\hline Arachnolasma sp. & $*$ & & & & & & $*$ & $*$ & \\
\hline Aulophyllum fungites & $* * * *$ & & & & * & $* * *$ & $* * *$ & $*$ & $* *$ \\
\hline Axophyllum densum & $* * *$ & & $*$ & * & * & $*$ & $*$ & $*$ & $*$ \\
\hline Axophyllum lonsdaleiforme & $*$ & & & & & & & & * \\
\hline Axophyllum nanum & $* * * *$ & & $*$ & $* *$ & * & $*$ & $* *$ & $*$ & $*$ \\
\hline Axophyllum pseudokirsopianum & $*$ & & & & & $*$ & $*$ & & \\
\hline Axophyllum sp. & $*$ & & & & & $*$ & $*$ & & \\
\hline 'Bothrophyllum' lateseptatum & $*$ & & & & & $*$ & $*$ & & \\
\hline Caninophyllum halkynense & ** & & & & & * & * & & \\
\hline Clisiophyllum crassiseptatum & $* *$ & & & & & $*$ & $*$ & * & \\
\hline Dibunophyllum bipartitum & $* * * *$ & & & & $*$ & $* * *$ & $* * *$ & $* *$ & $* *$ \\
\hline Dibunophyllum sp. & $*$ & & & & & $*$ & $*$ & & \\
\hline Diphyphyllum fasciculatum & $*$ & & & & $*$ & & $*$ & & \\
\hline Diphyphyllum furcatum & $* *$ & & & & $*$ & & $* *$ & & \\
\hline Diphyphyllum lateseptatum & $* * *$ & & & * & $* *$ & $*$ & $* * *$ & $*$ & $* *$ \\
\hline Diphyphyllum maximum & $*$ & & & & & & & & $*$ \\
\hline Enniskilenia enniskileni & $* *$ & & & & & $*$ & $*$ & & * \\
\hline Gangamophyllum sp. & $*$ & & & & & $*$ & $*$ & & \\
\hline Guadatia sp. & $*$ & & & & & $*$ & $*$ & & \\
\hline Haplolasma cf. densum & * & & & & & * & * & & \\
\hline 'Kizilia' sp. & $*$ & & & & & * & $*$ & & \\
\hline Koninckophyllum interruptum & $*$ & & & & * & $*$ & $*$ & $*$ & $*$ \\
\hline Koninckophyllum magnificum & $*$ & & & & * & $*$ & $*$ & $*$ & \\
\hline Lithostrotion decipiens & $* *$ & & & & $*$ & & $* *$ & & \\
\hline Lithostrotion maccoyanum & $* * *$ & $* * *$ & & & & * & $* * *$ & & * \\
\hline Lithostrotion vorticale & $* *$ & & & & $*$ & * & $* *$ & & \\
\hline Lonsdaleia aff. duplicata & $* *$ & & & & & & & & $*$ \\
\hline Lonsdaleia sp. & $*$ & & & & & & & & $*$ \\
\hline Palaeosmilia murchisoni & $* *$ & & & & & $*$ & $*$ & & * \\
\hline Palastraea cf. carbonaria & $*$ & & & & & & & & * \\
\hline Pareynia spendens & $* *$ & & & & & & & & * \\
\hline Pseudozaphrentoides juddi & $* * * *$ & & & & & $* * *$ & $* * *$ & $*$ & * \\
\hline Rylstonia cf. benecompacta & $*$ & & & & & $*$ & $*$ & & \\
\hline Siphonodendron aff. junceum & $*$ & & & & & & & & $*$ \\
\hline Siphonodendron intermedium & $* * *$ & & & & $* *$ & * & $* * *$ & & \\
\hline Siphonodendron irregulare & $*$ & $*$ & & & & & $*$ & & * \\
\hline Siphonodendron junceum & $* * * *$ & $* * *$ & * & * & $* *$ & $* *$ & $* * * *$ & & $*$ \\
\hline Siphonodendron martini & $* * * *$ & & & $*$ & $* * * *$ & $*$ & $* * * *$ & $*$ & $*$ \\
\hline Siphonodendron pauciradiale & $* * * *$ & * & & * & $* *$ & $* *$ & $* * *$ & $*$ & $* * *$ \\
\hline Siphonophyllia samsonensis & $*$ & & & & & * & $*$ & & \\
\hline Siphonophyllia sp. & * & & & & & & & & $*$ \\
\hline total Rugosan species & 42 & 4 & 3 & 5 & 15 & 29 & 34 & 12 & 22 \\
\hline total Rugosan genera & 35 & 2 & 2 & 3 & 6 & 18 & 22 & 9 & 13 \\
\hline Heterophyllia ornata & $* * * *$ & * & * & $*$ & * & $*$ & $* *$ & * & * \\
\hline Hexaphyllia mirabilis & $* * *$ & $*$ & $*$ & $*$ & $*$ & $*$ & $* *$ & $* *$ & $* *$ \\
\hline Syringopora sp. 1 & $* *$ & $* *$ & & & & & $*$ & $*$ & \\
\hline Syringopora sp. 2 & $*$ & & & & * & & * & & \\
\hline cladochonid & $*$ & & & & $*$ & & $*$ & & \\
\hline chaetetid & $* *$ & & & & * & $*$ & $*$ & & * \\
\hline multithecoporid & $*$ & & & * & & & $*$ & & \\
\hline roemeriporid & $*$ & & & & & & & & $* *$ \\
\hline total coral species & 50 & 7 & 5 & 9 & 20 & 31 & 41 & 15 & 26 \\
\hline total coral genera & 30 & 5 & 3 & 5 & 11 & 21 & 29 & 11 & 17 \\
\hline
\end{tabular}

Table 1. Distribution and abundance of corals in the dominant facies and units of Royseux. Legend: *: rare, **: scattered, ***: common, ****: abundant. From Poty (1981) and Denayer et al. (2011), updated and completed (total: 290 specimens). 

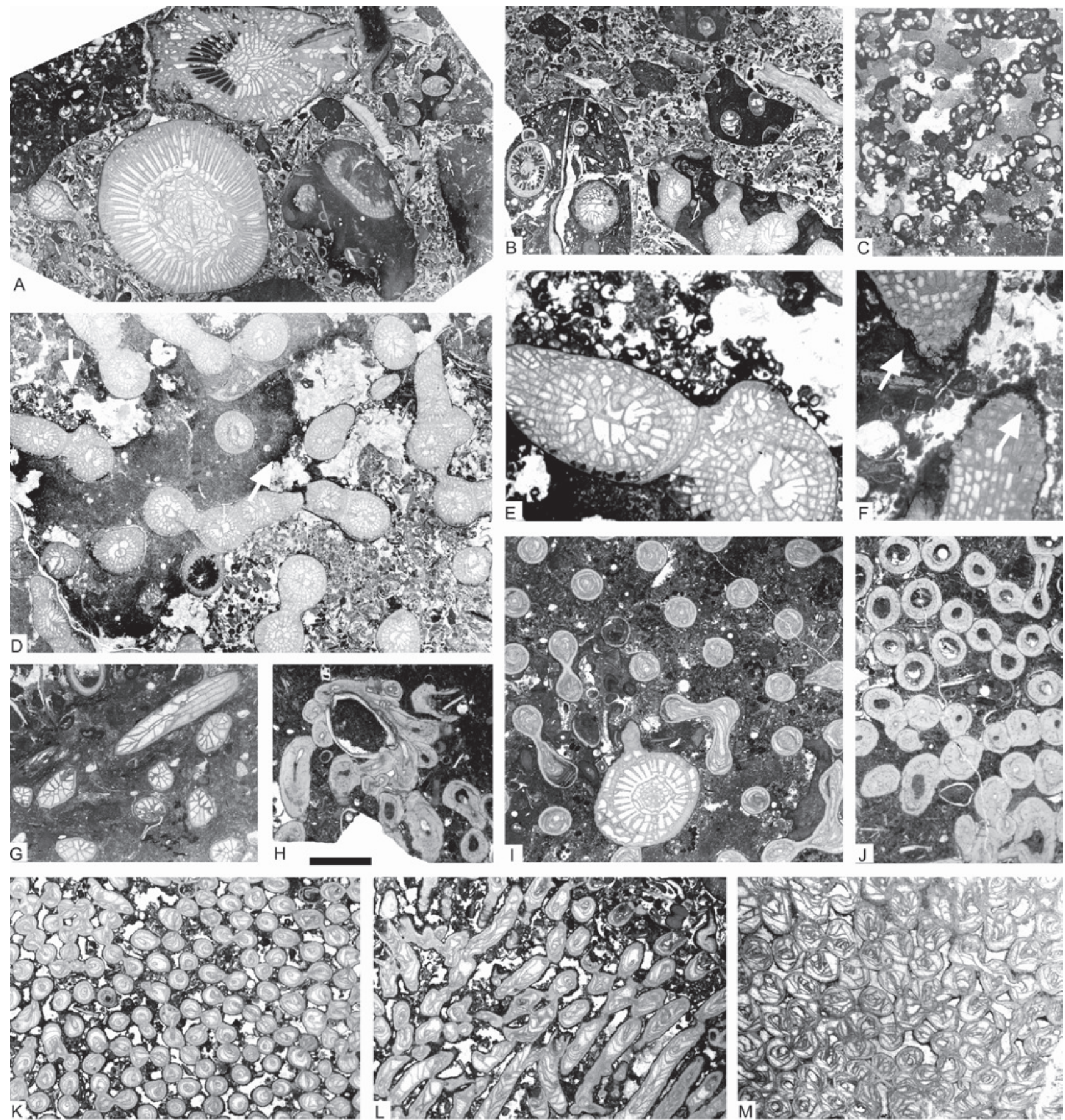

Figure 3. Facies and corals from the Chabôfosse facies of Royseux. A: limestone conglomerate with reworked pebbles of several distinct facies as well as corals, the solitary coral at the base is Clisiophyllum crassiseptatum with perfectly preserved epitheca suggesting that it grew amongst the pebbles very shortly after their deposition (ULg.PA.Roy.III.66b). B: conglomerate with limestone pebbles of reworked fragments of Siphonodendron ssp. colonies (ULg.PA.Roy.III.272). C: microconchids associated with microbial-algal build-ups from the uppermost facies of sequence +2 (ULg.PA.Roy.III.271). D: Siphonodendron intermedium colony partly included in a pebble (darker facies), partly free suggesting etheir that the reworking occurred quickly and on short distance or possibly that the survived the reworking and continued to grow afterwards, or a 'patchy' diageneses of the matrix (ULg.PA.Roy113a). E: close-up view of D showing microconchids encrusting edges of the pebble and free corallites. F: Diphyphyllum lateseptatum reworked in the conglomerate with margin burrowed by endoliths (arrows) suggesting that reworking was short-lived and was followed by a period of relative calm and slow sedimentation (ULg.PA.Roy.III.273). G: Hexaphyllia ornata from the upper biostrome of sequence +2 (ULg.PA.Roy.III.120). H: Undetermined cladochonid growing on a brachiopod shell (ULg.PA.Roy.III.244b). I: Axophyllum simplex settled within a colony of Syringopora sp. 1 (ULg.PA.Roy.III.89). J: Undetermined multithecoporid with variously thickened thecae (ULg.PA.Roy.III.244). K-L: Syringopora sp. 2 in transverse and longitudinal section (ULg.PA.Roy. III.249). M: Roemeripora sp. in transverse section, from sequence +9 (ULg.PA.Roy.I.274). Scale bar equals $10 \mathrm{~mm}$ for A, B, D and E and $5 \mathrm{~mm}$ for C, F-M.

\section{Settings}

The Royseux locality is situated in the Dinant Synclinorium, a part of the Variscan Complex present in Southern Belgium. During Devonian and early Carboniferous times, the Dinant Synclinorium belonged to a narrow platform stretching along the south coast of the London-Brabant Peninsula (Laurussia) from the Aachen area (westernmost Germany) in the east to the Bristol area (United Kingdom) in the west. The Belgian part of this platform is traditionally named the Namur-Dinant Basin.
This 'basin' - in fact a half-graben - was subdivided into several sedimentation areas by Hance et al. (2001).

Royseux is located in the central part of the Namur-Dinant Basin, and thus belongs to the Condroz Sedimentation Area (CSA). A thick sequence of shallow-water limestone was deposited in this sedimentation area during Warnantian (late Viséan) time. The Warnantian succession is subdivided in ascending order into the Bonne (Thon-Samson and Poilvache members) and Anhée formations (Poty et al., 2006). The latter includes unusual coral biostromes and coralliferous beds (Aretz, 2001; Fig. 2), which 
correspond to the Chabôfosse Facies sensu Poty et al. (2001). Detailed description of the sections is available in Poty et al. $(1988,2011)$ and Aretz $(2001,2002)$ and is briefly summarised here. The base of the Anhée Formation (Fm) rests on a palaeosol capping the sequential stromatolitic and oncolitic limestones of the Poilvache Member and corresponds to a shift in sedimentation from deepening-upward to shallowing-upward parasequences (recorded by sequence +2 of Pirlet, 1968). All succeeding sequences follow this trend and start with loosely packed bioclastic wackestone passing to packstone then grainstone to rudstone; the top of the sequences are micritic and microbial wackestones. Bioclasts are mainly fragments of echinoderms, brachiopods, corals, bryozoans and foraminifers. Less common facies include Saccaminopsis wackestone, microbial boundstone associated with microconchids ('vermetid gastropods' in older literature) and coral bafflestone (Aretz, 2001). Two coral horizons occur in the succession, at the base and top of parasequence +2 . The first horizon (Fig. 2) is a Siphonodendron junceum and Lithostrotion maccoyanum bafflestone that rests on crinoidal rudstone and is succeeded by a monospecific layer of S. junceum. Siphonodendron pauciradiale, syringoporids and heterocorals occur at the top of this first biostrome. The middle part of parasequence +2 yields a rich and diverse fauna of colonial (mainly Siphonodendron ssp.) and solitary rugose corals (Dibunophyllum bipartitum), whereas chaetetides and syringoporides occur sporadically. Brachiopods are abundant and dominated by spiriferides and productides, including representatives of the Subfamily Gigantoproductinae. The second biostromal horizon starts with a $S$. junceum bafflestone with a bioclastic wackestone-packstone matrix, capped by a poorly sorted pebbly rudstone (up to $25 \mathrm{~cm}$-thick) containing well rounded fragments of colonies (Siphonodendron ssp., Diphyphyllum ssp.) and numerous solitary rugose corals. This conglomerate was interpreted as a storm deposit by Aretz (2001). The diversity is at a maximum in this conglomeratic layer, both for rugose corals (31 species, Table 1) and brachiopods (10 species). The biostrome ends with a Siphonodendron martini bed resting on the conglomerate and is capped by a microbial-algal crust associated with microconchids that marks the boundary with the next parasequence. Parasequence +3 starts with bioclastic wackestone-packstone containing some corals and Saccaminopsis wackestone and is topped by a horizon formed by small microbial-heterocoral-microconchid build-ups (Fig. 3C). Parasequences +4 to +8 are relatively rich in fauna (Poty et al., 1988) but poorly exposed. The first late Warnantian (Brigantian) fauna appear in parasequence +9 (see Poty et al., 1988).

\section{Faunal assemblages}

In the stratigraphical interval studied, six lithological units are recognised: five in parasequence +2 (first biostrome, intermediate bioclastic beds, gigantoproductines beds, second biostrome, and conglomerate; see previous section); a further unit consists of the fossiliferous beds immediately overlying the second coral horizon (parasequence +3 ). These six units are characterised by their fossil assemblage (Table 1). Sampling for groups other than corals (i.e. brachiopods, molluscs, foraminifers) is less precise and assemblages are available for groups of units.

\subsection{Rugose corals}

The lower coral biostrome (Fig. 2) yields a bi-specific assemblage of Siphonodendron junceum and Lithostrotion maccoyanum in colonies to $60 \mathrm{~cm}$ in diameter. It is classified as a low-medium diversity coral biostrome (class C2 in Aretz, 2010). Very rare Siphonodendron irregulare and S. pauciradiale occur. Overlying bioclastic strata are relatively poorly fossiliferous and contain a few colonies of $S$. junceum together with the solitary taxa Axophyllum nanum and A. densum. This unit corresponds to a low diversity level-bottom community (A2 in Aretz, 2010) possibly owing to the development of very shallow-water facies (Aretz et al., 2010). The diversity increases again in the gigantoproductines beds that recorded the next deepening. In addition to the previously listed species, Siphonodendron martini, S. pauciradiale and Diphyphyllum sp. occur in colonies tens of centimetres across (class A1 of Aretz, 2010). The diversity increases rapidly with the
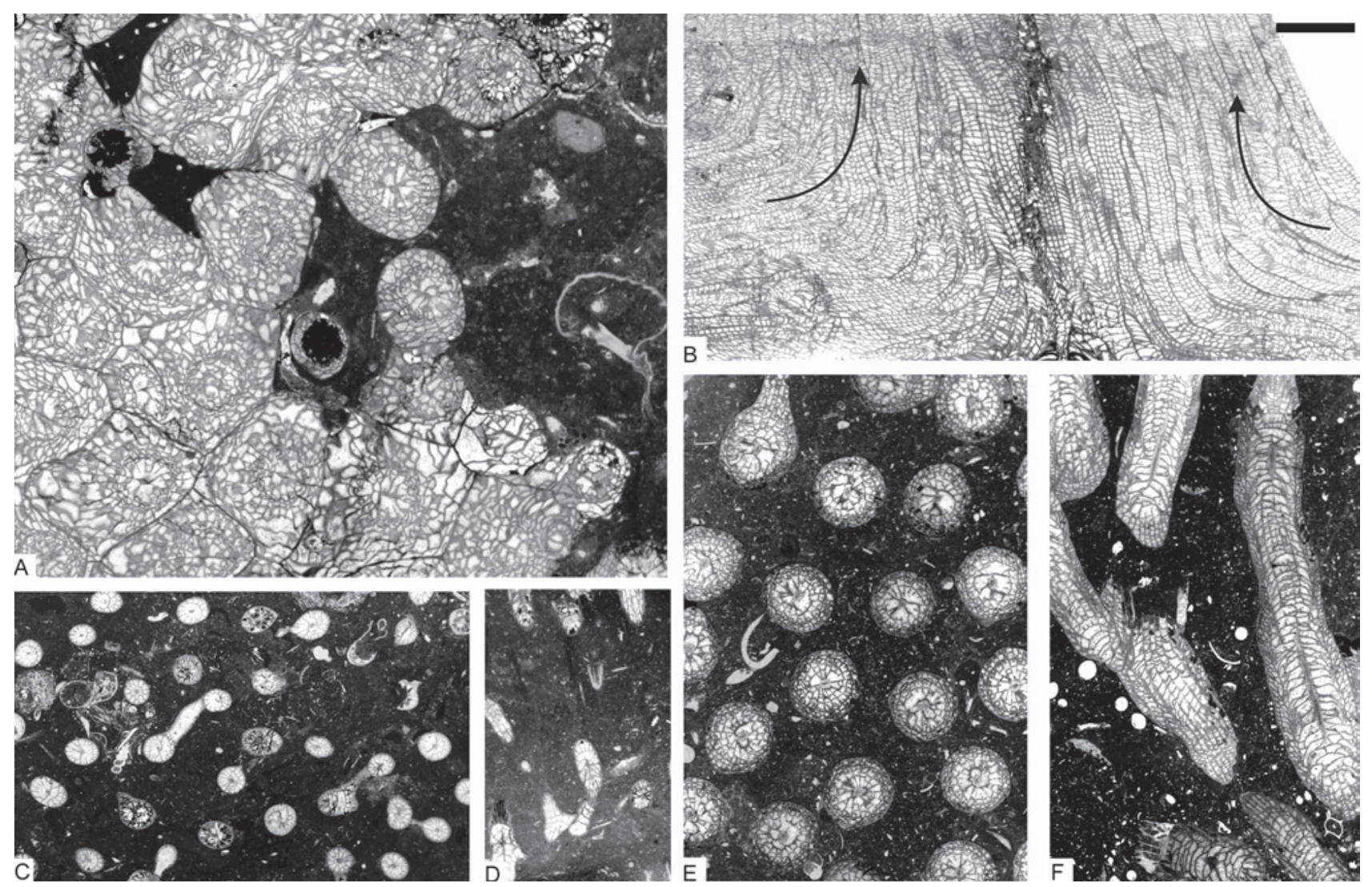

Figure 4. Colonial rugose corals from sequence +2 of the Chabôfosse facies of Royseux. A: sub-cerioid colony of Lithostrotion vorticale showing subcylindrical corallites (ULg.PA.Roy.III.254). B: Two colonies of Lithostrotion maccoyanum converging then growing parallel to each other (ULg.PA.Roy. III.252). C-D: Siphonodendron irregulare (ULg.PA.Roy.III.175). E-F: Siphonodendron aff. junceum characterised by very small corallites, 1 mm or less in diameter (ULg.PA.Roy.III.210). Scale bar equals $5 \mathrm{~mm}$ for A-F. 


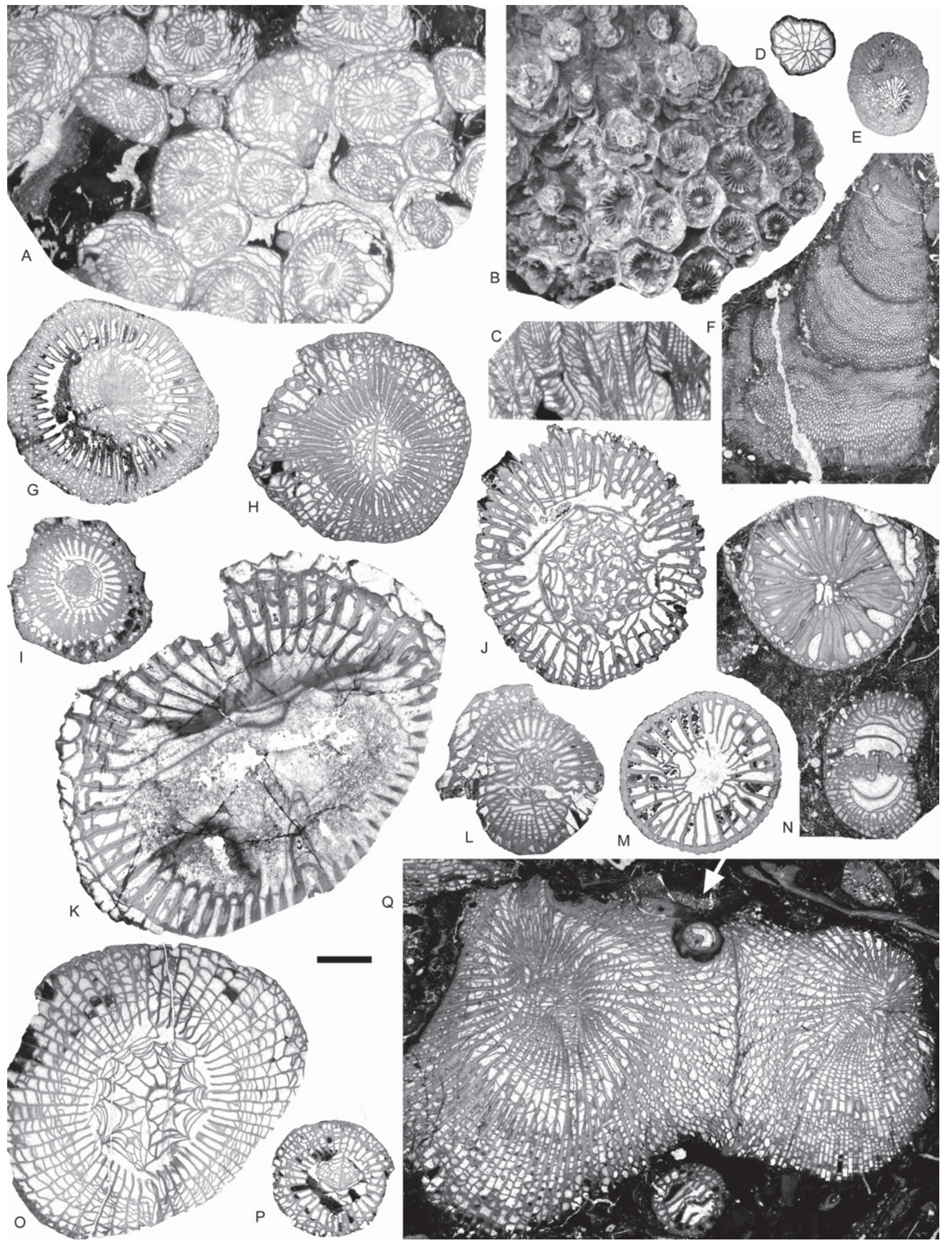

Figure 5. Rugose corals and chaetetid from the Chabôfosse facies of Royseux. A-C: Lonsdaleia sp. from sequence +9 showing a sub-cerioid trend (ULg. PA.Roy.I.217), A: transverse section, B: external view of corallum, C: longitudinal section. D: Heterophyllia ornata (ULg.PA.Roy.II.234). E: 'Kizilia' sp. from sequence +2 (ULg.PA.Roy.III.92). F: cf. Chaetetes depressus from sequence +2 (ULg.PA.Roy.III.234/I/i). G: Amygdalophyllum sp. 1 (ULg.PA.Roy. III.221/I). H: Arachnolasma sp. (ULg.PA.Roy.III.108b). I: Axophyllum lonsdaleoides (ULg.PA.Roy.III.178). J: Gangamophyllum cf. boreale (ULg.PA.Roy. III.173). K: Siphonophyllia samsonensis (ULg.PA.Roy.III.223). L: Axophyllum sp. 2 (ULg.PA.Roy.III.154/II). M: Enniskillenia enniskilleni from sequence +9 (ULg.PA.Roy.III.142a). N: Siphonophyllia sp. (juvenile?) and Diphyphyllum maximum (ULg.PA.Roy.III.207a). O: Dibunophyllum bipartitum forma 'craigana' (ULg.PA.Roy.III.155). P: Dibunophyllum sp. (ULg.PA.Roy.III.233/II). Q: Palastraea cf. carbonica with chaetetid sponges and microconchids (arrow) from sequence +9 (ULg.PA.Roy.III.153). Scale bar equals $10 \mathrm{~mm}$ for B and $5 \mathrm{~mm}$ for A, C-Q. 
development of the second biostrome in which Siphonodendron martini (in large colonies) is highly dominant, whereas $S$. intermedium, S. pauciradiale, S. junceum, Clisiophyllum crassiseptatum (Fig. 3A) and Dibunophyllum bipartitum are very common. Additionally, scattered Lithostrotion vorticale, L. decipiens, Diphyphyllum lateseptatum, Aulophyllum fungites, Pseudozaphrentoides juddi, Axophyllum nanum, and Axophyllum densum are moderately abundant but Diphyphyllum furcatum, $D$. fasciculatum, Koninckophyllum interruptum and K. magnificum are rather rare. The remarkable conglomerate horizon that occurs in the median part of the second biostrome consists of reworked, recently formed limestone including coral colonies. The preservation of corals in the conglomerate is very good, probable evidence of short transport distances. Solitary corals appear either as reworked elements (in pebbles or matrix-free, Fig. 3A-B) and as autochthonous fauna that seemingly grew up in the gravel after its deposition. These corals include Aulophyllum fungites and Dibunophyllum bipartitum (both abundant, Fig. 4O), Dibunophyllum sp. (rare, Fig. 4P), Palaeosmilia murchisoni, Caninophyllum halkynense (both common), 'Botrophyllum' lateseptatum (rare), Koninckophyllum magnificum (rare), K. interruptum, Siphonophyllia samsonensis (very rare, Fig. 4K), Pseudozaphrentoides juddi (very common), Haplolasma cf. densum, Gangamophyllum densitabulata (rare, Fig. 4J), Axophyllum nanum (common), A. densum, A. pseudokirsopianum (rare), A. sp. (rare, Fig. 3L), Rylstonia cf. benecompacta (rare), Guadatia sp. (rare), Amygdalophyllum sp. (Fig. 4G), 'Kizilia' sp. (very rare, Fig. 4E) and Enniskillenia enniskilleni (occasional, Fig. 4M). The overlying strata of parasequence +3 yield a less diversified fauna dominated by Siphonodendron martini, S. pauciradiale, Diphyphyllum fasciculiseptatum, Aulophyllum fungites and Dibunophyllum bipartitum, together with Clisiophyllum crassiseptatum, Arachnolasma sp. (Fig. 4H), Pseudozaphrentoides juddi, Axophyllum nanum and A. densum. Each species is known from older strata. A supplementary, younger unit (parasequences $+8 / 9$, RC8 biozone of Poty et al., 2006) is described here also because of its relatively high diversity. Siphonodendron pauciradiale is highly dominant, but $S$. martini, $S$. junceum, $S$. aff. junceum (a species with very small diameter corallites, Fig. 5C-D), Lithostrotion maccoyanum (Fig. 5B), Diphyphyllum lateseptatum, D. maximum, Aulophyllum fungites, Dibunophyllum bipartitum, Koninckophyllum interruptum, Siphonophyllia sp. (Fig. 4N), Pseudozaphrentoides juddi, Palaeosmilia murchisoni, Axophyllum nanum, A. densum, A. lonsdaleiforme (Fig. 3I), Lonsdaleia duplicata and an as yet undescribed Lonsdaleia species (Fig. 4A-C), Palastraea cf. carbonaria (Fig. 4Q), Pareynia splendens and Enniskillenia enniskilleni are common in several beds.

\subsection{Tabulate corals}

Curiously, tabulate corals are rather uncommon in the locality, possibly for reasons of facies issues and/or competition with rugose corals (particularly with Siphonodendron junceum). Syringopora sp. 1 (Fig. 3I) is common only in the lower part of the first biostrome. Syringopora sp. 2 (with smaller corallites than S. sp. 1, Fig. 3K-L) occurs scattered in the second biostrome and parasequence +9 . Cladochonids occur sporadically in the second biostrome and its conglomerate (Fig. 3H), whereas a single occurrence of multithecoporids (Fig. 3J) occurs in the gigantoproductine beds of parasequence +2 . Roemeriporids (Fig. $3 \mathrm{M}$ ) are known only in parasequence +9 .

\subsection{Heterocorals}

Heterophyllia ornata and Hexaphyllia mirabilis are relatively common and occur in all the units but are particularly abundant in the small microbial build-ups of unit +4 (Fig. 3G, 5D).

\subsection{Sponges}

Chaetetids are scattered in the second biostrome and in the conglomerate, invariably as small colonies (Fig. 5F). Siliceous sponge spicules were observed in various units but none have been studied systematically.

\subsection{Microfossils}

Conodont, algal and foraminiferal assemblages were investigated in a MSc thesis (Laurent, 1985) in collaboration with $\mathrm{R}$. Conil and M. Laloux. No exhaustive lists are available for the individual groups, but Laloux (1988) qualified the diversity of the foraminifers of Royseux as one of the highest ever recorded in the Namur-Dinant Basin.

\subsection{Brachiopods}

The Royseux brachiopod (at least 18 species) contains some remarkable horizons rich in large-sized productidines (Gigantoproductus giganteus, Figs 6, 7B). This is so far the best

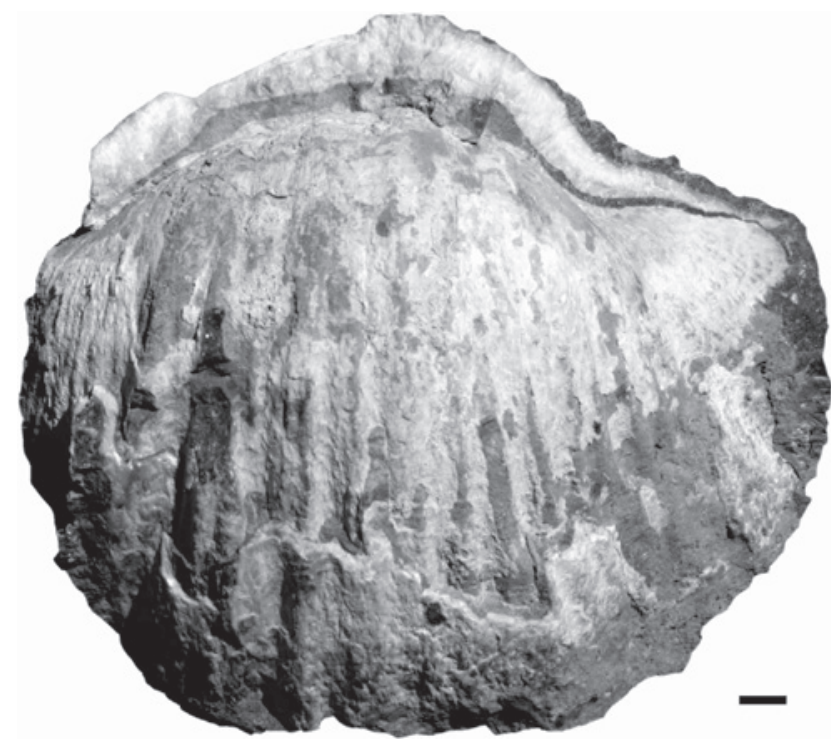

Figure 6. Gigantoproductus giganteus, ULg.PA.2015.08.01/1, incomplete large-sized specimen (mostly the dorsal external mould) with shelly fragments of dorsal and ventral valves. Note the thick ventral valve and the strong longitudinal plications. Scale bar equals $10 \mathrm{~mm}$.

locality in Belgium to observe them in situ even if representatives of the Subfamily Gigantoproductinae were reported, but not illustrated (except de Koninck, 1847), elsewhere in the NamurDinant Basin (see e.g. references in Mortelmans \& Bourguignon, 1954; Demanet, 1958). Besides this emblematic species, the brachiopod fauna includes chonetidines (Megachonetes sp., Fig. 7A), other productidines (Antiquatonia sp., Fig. 7C-E), Avonia sp. (Fig. 7F-G), Echinoconchus punctatus (Fig. 7H$\mathrm{K})$, Echinoconchella sp., Semiplanini gen. et sp. indet. (Fig. 7L), productide gen. et sp. indet., unidentified orthotetides, orthides (Schizophoria resupinata, Fig. 7M), rhynchonellides (Propriopugnus? sp.), athyridides (Actinoconchus sp., Fig. 7N), spiriferides (Podtsheremia ssp., possibly two species) (Fig. 7O), elythid gen. et sp. indet., spiriferide (two undetermined genera and species), and undetermined terebratulides. These data should be considered as preliminary pending on thorough systematic study of additional material collected from each horizon (some species are represented by only a single specimen whereas the gigantoproductines are over-represented); hence, most brachiopods are here left in open nomenclature. Parasequence +2 yields some unidentified orthotetides, Schizophoria resupinata, Podtsheremia sp., spiriferide gen. et sp. indet. 1 . The second biostrome yields Antiquatonia sp., Avonia sp., G. giganteus, Podtsheremia sp., spiriferide gen. et sp. Indet 2. The conglomerate contains Antiquatonia sp., Avonia sp., Schizophoria gr. resupinata, G. giganteus, Semiplanini gen. et sp. indet., Echinoconchus punctatus, orthotetide gen. et sp. indet., Propriopugnus? sp. The overlying strata (parasequence +3 ) yield Echinoconchus punctatus and productide gen. et sp. indet. and other undetermined taxa.

The degree of articulation of the shells and the state of preservation of delicate ornamental elements (e.g. spines, frills) rank among the most significant factors for establishing the assemblage type (Brunton, 1987). Nevertheless, it is difficult to 


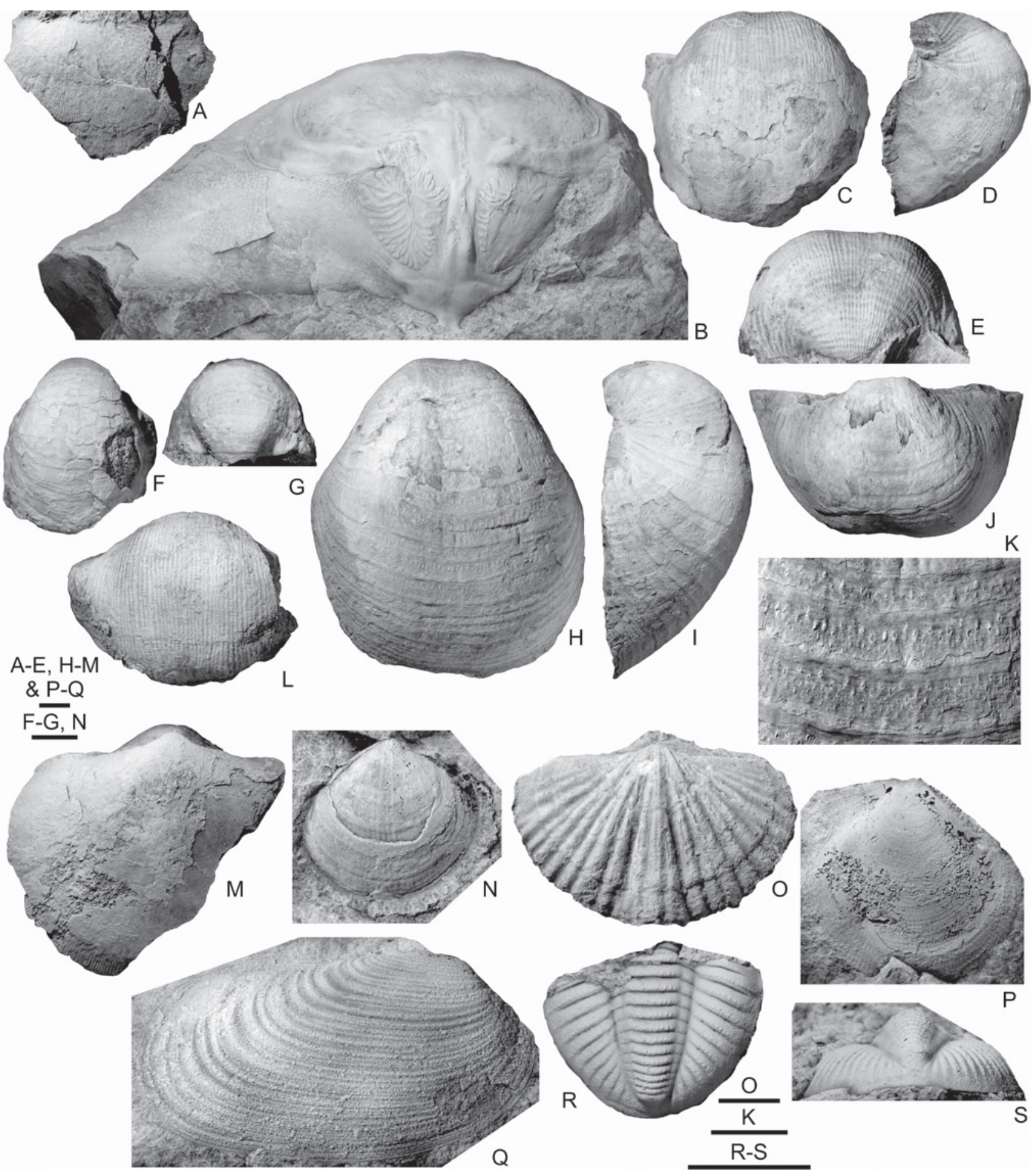

Figure 7. Brachiopods, trilobites and molluscs from the Chabôfosse facies of Royseux. A. Megachonetes sp., ULg.PA.2015.08.01/2, incomplete specimen in ventral view. B. Gigantoproductus giganteus, ULg.PA.2015.08.01/3, incomplete dorsal interior in posterior view (note the dendritic adductor muscle scars). C-E. Antiquatonia sp., ULg.PA.2015.08.01/4, almost complete ventral valve in ventral, lateral and posterior views. F-G. Avonia sp., ULg.PA.2015.08.01/5, incomplete ventral valve in ventral and posterior views. H-K. Echinoconchus punctatus, ULg.PA.2015.08.01/6, slightly distorted specimen in ventral, lateral and posterior views, and close-up of spines in central part of ventral valve. L. Semiplanini gen. et sp. indet., ULg.PA.2015.08.01/13, incomplete ventral valve. M. Schizophoria resupinata, ULg.PA.2015.08.01/7, incomplete specimen in ventral view. N. Actinoconchus sp., ULg.PA.2015.08.01/8, dorsal valve with fragment of flanges. O. Podtsheremia sp., ULg.PA.2015.08.01/9, complete specimen in dorsal view. P. Limipecten sp., ULg.PA.2015.08.01/10. Q. Allorisma cf. sulcata, ULg.PA.2015.08.01/11. R-S. Unidentified trilobite gen. and sp., ULg.PA.2015.08.01/12, pygidium. Scale bars equals $5 \mathrm{~mm}$.

estimate the proportion of disarticulated specimens versus those with conjoined valves owing to the difficulty of extracting the brachiopods from the carbonate matrix, but many specimens are still articulated, especially among the spiriferides and the productidines. Actinochonchus sp. (only one specimen!) shows fragments of nonspinose flanges and some rare specimens (Antiquatonia sp.) show ventral halteroid spines reaching $1.5 \mathrm{~mm}$ in diameter and c. $20 \mathrm{~mm}$ in length. Their length is considerably less than those recorded in some productidines from the Viséan Molignée Formation (Delépine, 1928, e.g. plate 1, figures 1-4;
Mottequin et al., 2015a, figure 13A), which was interpreted as being preserved in a relatively low energy environment with turbiditic sedimentation. As explained by Muir-Wood \& Cooper (1960) for representatives of the genus Antiquatonia characterised by long trail, it is supposed that the posterior part of the shell was partly buried in carbonate mud with the trail protruding, and thus the hinge and ear spines served to anchor the shell. In contrast, representatives of the Subfamily Gigantoproductinae were devoid of such long hinge spines, but these very large-sized shells, with shelly thickening in their posterior part, were characterised by a 


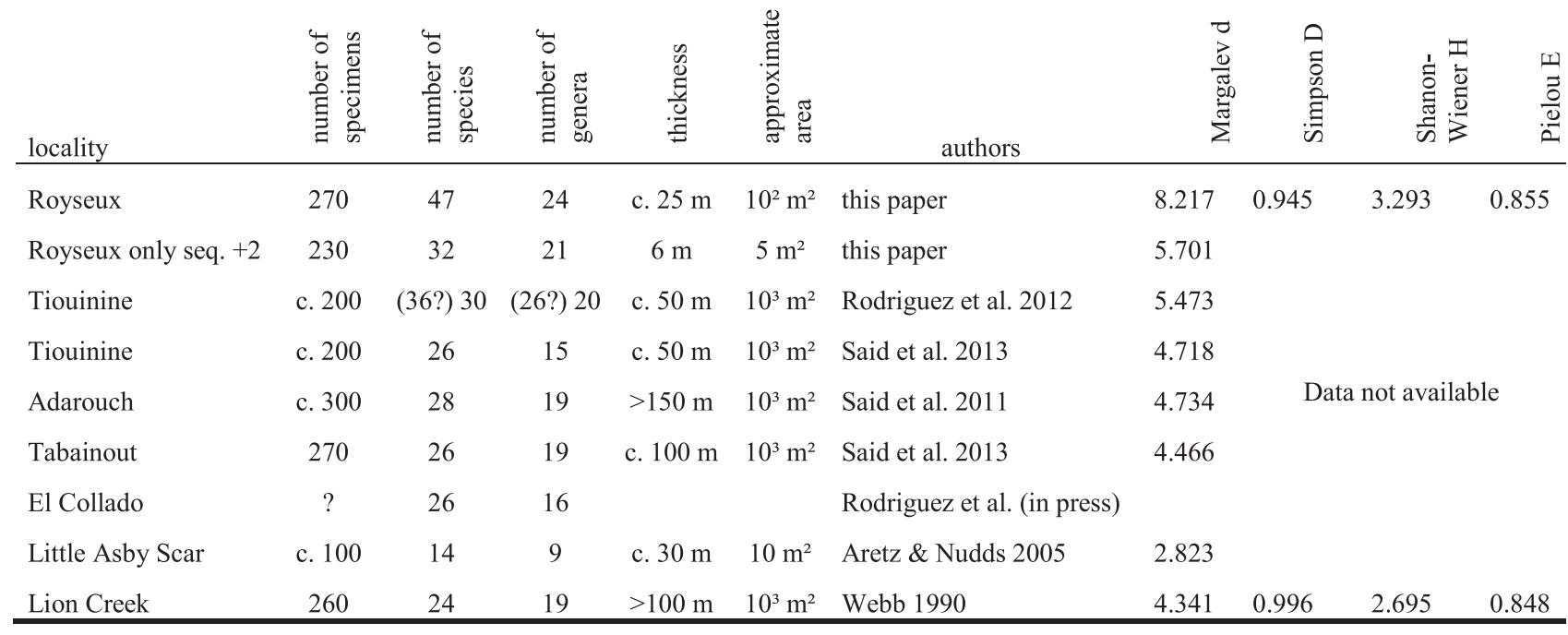

Table 2. Comparison of Royseux to other late Viséan fossiliferous sites based on rugose corals diversity and statistics.

thick and prominent ventral umbo that lay in the soft sediment with the long trail extending obliquely upward according to MuirWood \& Cooper (1960). Some of the large-sized G. giganteus at Royseux were preserved in life position.

\subsection{Molluscs}

Bivalves are rare throughout the succession. However, some specimens can be attributed to Limipecten sp. and Allorisma cf. sulcata (Figs 7P-Q). Microconchids (previously interpreted as vermetid gastropods) are locally abundant and form small buildups with microbialites, especially on top of sequences +2 and +4 . Scattered turreted and discoidal gastropods occur but have not been studied. Cephalopods are represented by rare orthoconic nautiloids.

\subsection{Arthropods}

Ostracodes and trilobites are common as fragments in thin sections from all facies and units. However, M. Bless determined some ostracode specimens for Laurent's MSc thesis in 1985, recognising Bairdiacea, Paraparchitacea and Shemonaellids. Trilobites may be abundant in the section but have not been studied in detail (Fig. 7R-S)

\subsection{Bryozoans}

Fragments of Cryptostomata, Fenestrata and Cystoporata occur scattered in thin sections but their diversity is still not estimated.

\section{Statistics}

Diversity metrics such as species diversity or various indices are in some studies regarded as convenient criteria to identify hotspots but should be interpreted more as windows into spatial diversity patterns that are not easy to quantify, even in living examples (Marchese, 2015).

The most commonly used proxy for palaeodiversity estimation is species richness, equivalent to Whittaker's (1972) $\alpha$-diversity, which corresponds to the total number of taxa (here total number of species or genera). This is the easiest index to calculate but it is not very useful for comparison between sites. Margalev's index d $=(\mathrm{S}-1) / \ln \mathrm{N}$, where $\mathrm{S}$ is the total number of species $(=\alpha$-diversity) and $\mathrm{N}$ the total number of specimens provides a better idea of the diversity as it takes into account the size of the collection. However the index is sensitive to species represented by small numbers of specimens. The Shanon-Wiener, Simpson and Chao indexes are better proxies but one must require the number of specimens recorded for each species and these data are rarely available in the literature. However, they are provided here in Table 2 for the Royseux locality and some other sites.

The rarefaction curve (Fig. 8C) computed for corals is asymptotic showing that the sampling is representative of the diversity because a larger sample would not significantly increase the diversity. The same curve computed for brachiopods indicates that the sampling is not comprehensive and that higher diversity is expected in a larger sample. Moreover, the stratigraphic distribution differs for corals and brachiopods. Obviously, the corals are more abundant in the biostromes, but both groups are most diverse within the conglomeratic level, suggesting mixing (see next section).

Coral occurrences in the six lithological units are summarized in Table 1. Figure 8 indicates the proportion of each genus in the sample and shows that colonial rugose corals and dissepimented solitary corals with axial structure account for c. $40 \%$ each, whereas non-columellate dissepimented solitary corals constitute less than $15 \%$. The remaining 5\% corresponds to Enniskillenia enniskilleni, the only undissepimented corals known in the Royseux section. The coral disparity is therefore rather low with few morpho-groups sizes which individually show little range of size (massive colonies with/without columella, fasciculate colonies with/without columella, dissepimented solitaries with/ without axial structure, undissepimented solitaries).

The high abundance of colonial and columellate solitary corals possibly reflects facies dominance as discussed below.

\section{Comparison}

\subsection{Rugose coral fauna}

The Royseux coral assemblage has high biodiversity, one of the highest in the Viséan (see below). But potentially how high could the diversity be? The statistical data discussed in the previous section provide some insight. However, a comparison with other Late Viséan localities exhibiting 'high diversity' gives a different perspective.

The Visé locality, time-equivalent of the sections at Royseux, is situated within the same biogeographic area as during the late Viséan and has reef facies with a very diverse fauna of brachiopods and molluscs (e.g. gastropods, bivalves, Demanet, 1958 and references within), but interestingly, the rugose and tabulate corals are not particularly diverse (36 species distributed among 23 genera after Poty, 1981). Nevertheless, the amount of described material is not very great, the locality is no longer accessible for additional sampling and is, in general, poorly known (Poty, 1981).

The c. 30 m-thick section at Little Asby Scar (Asbian) in Northern England yields 14 coral species distributed among nine genera and time-equivalent Siphonodendron biostromes cropping out in various localities in Ireland have much lower diversity with only 14 species distributed among 11 genera, mostly dominated by colonial forms (Aretz et al., 2010). 
Figure 8. Diversity statistics. A: Proportions of rugose coral genera within the Royseux assemblage (based on 290 specimens in thin section) showing the co-dominance of colonial forms and solitary corals with an axial structure and the minor occurrence of undissepimented solitary corals. B: Proportions of brachiopod groups in the site, showing the dominance of the productidines, notably the gigantoproductines and associated forms. C: Rarefaction curves with $95 \%$ confidence-interval (grey areas) computed for corals and brachiopods showing that the sampling is far from complete for brachiopods but relatively comprehensive for corals. D: Frequency diagram of coral morpho-groups plotted against their diameter. Abbreviations:

A.: Arachnolasma,

B.: Bothrophyllum,

C.: Caninophyllum,

G.: Gangamophyllum.

A
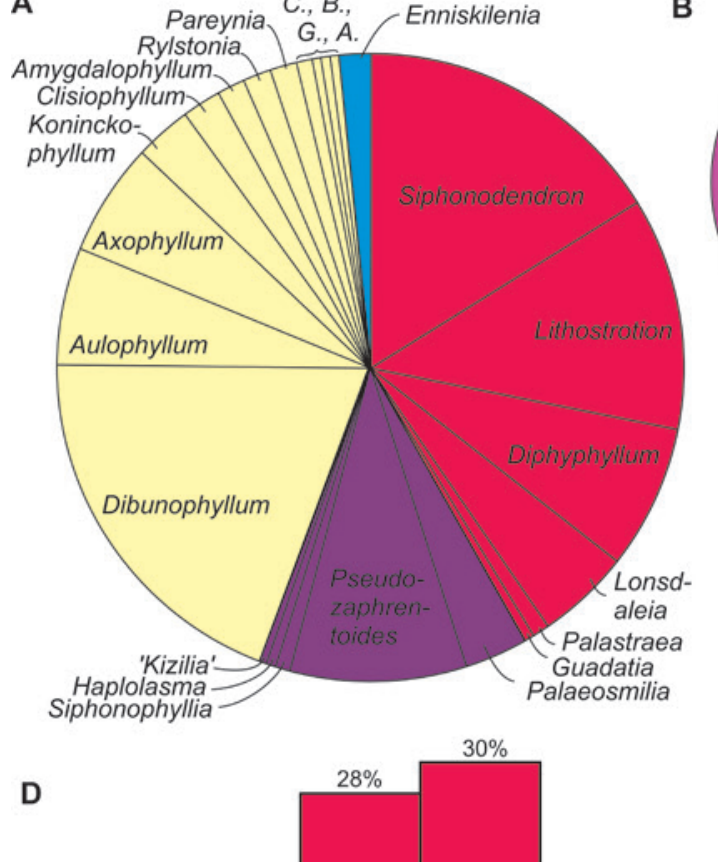

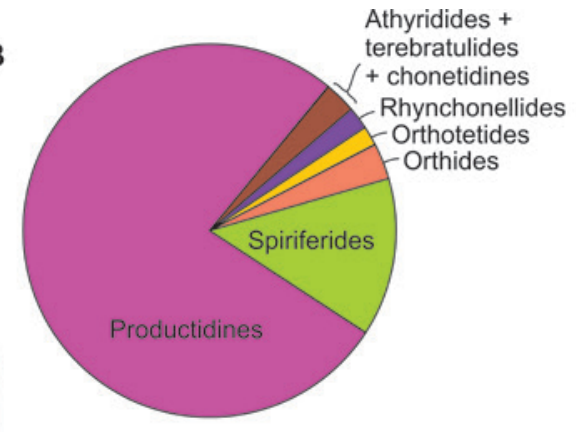

C

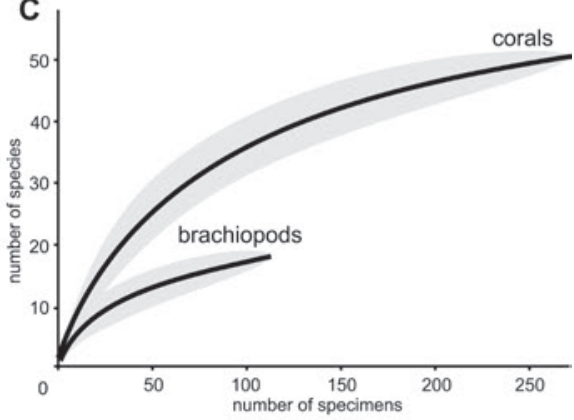

legend

colonial

solitary with axial structure

solitary without axial structure

undissepimented solitary

tabulate

heterocoral
The coral fauna of the late Viséan of Southern Spain (Guadatio area) was recently summarized by Rodríguez et al. (2016). These authors indicate 62 coral species distributed among 34 genera for the entire area (19 sections) and for the entire late Viséan. The richest section (El Collado) yielded 26 species distributed among 16 genera but corresponds to a time of accumulation of c. 5 Myr.

The late Viséan Lion Creek microbial-coral reefs of the Rockhampton Group in Queensland (Eastern Australia) yields 26 coral species distributed among 12 genera, of which nine species are undissepimented solitary rugose corals known only from microbial habitats (Webb, 1990). This diversity represents material from several reefs and peri-reefal facies scattered over a wide area.

Many localities in Morocco have yielded late Viséan rugose corals but only three of them are discussed here because of their high biodiversity. Rodríguez et al. (2012) indicated the occurrence of 36 coral species in 23 genera in according to the main text, but only 30 species in 20 genera are listed their table 1 , from the three c. $50 \mathrm{~m}$-thick Tiouinine sections, which include biohermal, peri-reefal and shaly facies of late Viséan age. Said et al. (2013) worked on the same material and listed only 26 species distributed among 23 genera ( 20 shown in the table) and 15 genera. Taking into account the larger variation in facies and the doubled thickness compared to Royseux, the Tiouinine locality is not so diverse, even considering the largest reported numbers, which need to be checked. Similarly, the Adarouch sections (Said et al., 2011) yielded 28 coral species (19 genera) from more than $150 \mathrm{~m}$ of section, including a wide spectrum of facies and ages (Viséan to Bashkirian). The Tabainout area yields 26 coral species (including six undissepimented solitary forms) in 19 genera (six undissepimented) from c. $100 \mathrm{~m}$ of section of various facies. In conclusion, the Moroccan localities owe their diversity to accumulation of taxa over longer time intervals that in fact dilute the diversity signals, which falsely increase because the larger variation in facies seems to enhance the diversity and disparity of corals.

Compared to the other localities, sequence +2 of Royseux, $6 \mathrm{~m}$-thick in total, yielded 32 species ( 21 genera) of rugose corals, which makes it the most diverse hotspot for the Late Viséan (and possibly for the whole Carboniferous) rugose corals worldwide (see Table 2 for a comparison). Finally, what is so special about Royseux? Corals are certainly diverse (and abundant) but do the other fossil groups develop a similar diversity and what can they add to the discussion?

During the late Viséan, the Namur-Dinant Basin was situated c. $10^{\circ} \mathrm{S}$ (Stampfli \& Borel, 2002). This is a similar latitudinal position present day Borneo, in the Indo-Pacific Coral Triangle, where coral biodiversity reaches its maximum (more than 700 species in 17 families of scleractinians, Hughes et al., 2013; Johnson et al., 2015). Of course the 700 species occur in a wide area of several thousands of square kilometres, but diversity does not decrease in a linear way when area decreases. Compared to the Recent, the coral diversity that would be expected in Royseux (a few hundreds of square metres) would be higher. For comparison, Heron Reef in the Australian Great Barrier Reef (c. $23 \mathrm{~km}^{2}$ without lagoon) yielded 120 coral species (Plaisance et al., 2011). However, a key point to consider is that fossil species and genera are based purely on morphology. Comparing fossil morpho-species of rugose and tabulate corals with biological species of extant scleractinian corals consequently is not easy, and mostly results in generally lower numbers of taxa for Palaeozoic coral assemblages.

\subsection{Brachiopod fauna}

At first view, the brachiopod diversity (at least 18 species, Fig. $8 \mathrm{~B})$ recorded at Royseux is not exceptional compared to those reported elsewhere in the Viséan of Western Europe, notably by Brunton (1987; 56 species) and Brunton \& Tilsley (1991; 125 species) in the Asbian of County Fermanagh (Northern Ireland) and Treak Cliff (Derbyshire), respectively. The degree of diversity is similar to that reported in the late Asbian Meenymore Formation (14 species) of northwest Ireland (Mottequin et al., 2015b), wherein 14 species were interpreted to be an in situ, but time-averaged accumulation. However, the brachiopods from Royseux all occur within a single $4^{\text {th }}$ order parasequence in comparison with the much longer time interval represented by 
Treak Cliff. The brachiopod fauna from some levels of the Zrigat Formation in eastern Tafilalt (Morocco), although probably underestimated, is quite similar to that of Royseux with 15 species, mainly including productides (e.g. Gigantoproductinae) and spiriferides (Mottequin et al., 2016). They are associated with a rich coral fauna, which is still only partly known (Aretz et al., 2013). It is currently difficult to compare and estimate the real diversity of the contemporaneous brachiopod fauna from Visé, which was described in the pioneering works of de Koninck (1842-1844, 1847, 1887) and Demanet (1934). These authors described several tens of species, but also erroneously included Frasnian material, such as 'Hypothyridina cuboides' (see de Koninck, 1842-1844) and Spirifer capillaris (see de Koninck, 1887). So far, only a small number of these many species has been revised (e.g. Muir-Wood \& Cooper, 1960; Brunton et al., 1994). Demanet (1958) recorded 26 species in the former 'V3b' unit of the Yvoir area (Dinant sedimentation area), i.e. the Thon-Samson, Poilvache and Anhée formations, but the time interval considered by Demanet (1958) is not comparable with the parasequence sampled at Royseux and Demanet's (1958) list of brachiopods has to be revised, but this is beyond the scope of this paper. It is worth noting that the brachiopod sampling is far from exhaustive compared to the corals as indicated by the rarefaction curve (Fig. $8 \mathrm{C})$. A comprehensive study would require additional material.

\section{Discussion}

\subsection{Coral assemblage}

As commonly observed in biostromal units, one characteristic of the coral fauna in Royseux is the dominant position of the colonial corals, here mainly Siphonodendron and Lithostrotion in the lower part, and of Diphyphyllum in the upper part of the sections (Aretz, 2001). Tabulate corals are not diverse and no species with large corallites are known from any facies (Fig. 8D). In the non-biostromal facies, solitary rugose corals dominate and show several striking features, as outlined below.

(1) The non-dissepimented taxa - the so-called Cyathaxonia fauna sensu Hill (1981) - are almost absent (Fig. 8A). Enniskillenia enniskilleni is the only recorded member and it is moreover a large-sized solitary taxon (see next point). These taxa are commonly found in shaly facies, but they are not restricted to deep-water settings as commonly suggested (e.g. Hill, 1981; Oliver, 1992) and are quite common in environments that were stressful for other corals, such as dysphotic, dysaerobic, coldwater, hyperhaline (?) and turbid environments. Obviously none of those environments are known in Royseux. However, small solitary undissepimented corals are not uncommon in microbialite facies (e.g. Webb, 1987; Mundy, 1994). Such facies occur in the capping beds of the Siphonodendron biostromes but no rugose corals are associated with them. Curiously, the undissepimented corals are replaced in that facies by heterocorals! Competitive displacement by heterocorals is a possible explanation for this absence but different ecological requirements might also explain the dominance of heterocorals. Similarly, the simple rugose coral Amplexus coralloides, which is rather common in all environments in the Carboniferous is unknown in Royseux, possibly for similar reasons.

(2) The caninimorphic corals are poorly represented in the assemblage, both in number of species and in specimens, with Pseudozaphrentoides juddi and Siphonophyllia sp. being the only members of the morphotype (Fig. 8A, D). These forms are usually regarded as possible 'mud-stickers' (Hubbard, 1970; Aretz et al., 2010) and the absence of mud in Royseux may explain their rarity. The lack of an axial structure may have been tentatively interpreted as unfavourable for these corals, considering the numerous axophyllids, clisiophyllids, amygdalophyllids and Dibunophyllum that proliferated in Royseux.

(3) The typical range of corallum diameter of the solitary corals, all taxa considered, is relatively narrow (see Fig. 8D), as c. $60 \%$ of the collection has diameters ranging between 5 and $25 \mathrm{~mm}$. This distribution seems to indicate that the size optimum is linked to environment rather than taxonomy (cf. Hubbart, 1966). However, neither small ('Kizilia' sp.) nor very large (Siphonophyllia samsonensis) corals are common in any facies.
Among the solitary taxa with no axial structure, the $25-35 \mathrm{~mm}$ diameter range is largely dominated by Pseudozaphrentoides julii, whereas Palaeosmilia murchisoni is one of the only taxa with diameters greater than to $35 \mathrm{~mm}$ (the largest specimen is $70 \mathrm{~mm}$ wide). The solitary rugose corals with an axial structure have diameters dominantly between 10 and $25 \mathrm{~mm}$ but larger specimens of the same taxa (mainly Aulophyllum fungites, Dibunophyllum bipartitum and Caninophyllum halkynense) also occur. Hence, the disparity of the solitary rugose corals is much reduced. For the whole coral assemblage, the disparity is not high either and can be roughly but confidently approached by the number of high taxonomic categories (Ciampaglio, 2002): 8 families belonging to 6 suborders of rugose corals. The disparity (amount of morphological differences among taxa; Erwin, 1994) results from a series of constraints. The latter falls into two broad categories (Gould, 1988, 1989; Erwin, 1994): internal constraints (functional, structural, developmental, genetic, historical) and external constraints (environmental, ecological). The internal constraints are characters that do not interact directly with the physical world and results of developmental process (i.e. septal arrangement, fossula, axial structure). The external constraints corresponds to the characters that permit the taxa to withstand in its environment and ecosystem (i.e. skeletal habitus and thickening, size, septal length, etc.). Although both categories are not easily recognised, Erwin (2007) demonstrated that external constraints are the dominant factor determining morpho-space width, and thus that the disparity is ecologically-driven. In the present example, a low disparity would be interpreted as a low ecological constraint.

(4) Endemism is very low with only three taxa known only from Royseux (Siphonodendron aff. junceum, 'Bothrophyllum' lateseptatum and an undescribed new species of Lonsdaleia). There are no endemic genera. However, the faunal assemblage includes species that have been described from only one other area (e.g. Guadatia, only known from Southern Spain). Species in open nomenclature are not considered here because they are not sufficiently known (reduced material available). However, taxic diversity and endemism are commonly decoupled. Centres of endemism mostly occur on the periphery of hotspots (Reaka \& Lombardi, 2011; Reaka et al., 2008). This would be consistent with hotspot diversity resulting from the accumulation of taxa through time (Bellwood et al., 2012).

\subsection{Origin of biodiversity}

Biodiversity is a complex phenomenon controlled by various interplaying processes that have been and still are abundantly discussed. Several examples have been described in the literature, such as scleractinian diversity controlled in the recent oceans by tectonics (Wilson \& Rosen, 1998; Williams \& Duda, 2008; Bellwood et al., 2012), eustacy (Potts, 1983; Fulthorpe \& Schlanger, 1989), oceanic circulation pattern (Rosen, 1988; Veron, 2000), climate (Cowman et al., 2013; Bowen et al., 2013) and geological history of taxa (cf. Rosen, 1988, and references within). As summarized by Veron (2000), the diversity and biogeography of Recent scleractinian corals result from the superimposition of three patterns: (1) the diversity at the family level mostly reflects the geological history (climate and sea-level change, landmasses positions, extinction events) that occurred through the Cenozoic; (2) the diversity at the genus level results from the evolution of taxa settled in various biogeographic units; (3) the species diversity is the outcome of the oceanic circulation pattern during the last c. 5 Myr. At a finer scale (e.g. organism communities), the diversity is driven by a complex combination of resources availability, specialists/generalists coexistence, environmental variability and colonisation events as well as functional versatility of the organisms (Bellwood et al., 2006). Diversity is consequently produced by time-specific physical parameters (temperature, currents, landmasses position) but is also partly inherited from previous configurations (Veron, 2000; Karlson et al., 2004; Kiessling, 2009; Kiessling \& Kocsis, 2015).

If Royseux can be regarded as a biodiversity palaeo-hotspot - at least for the coral fauna - the question of the cause of this diversity remains open. Several hypotheses are tested here and discussed but none of them by itself is satisfactory and the best 
explanation probably rests in a combination of the different factors

(1) Facies. Several distinct facies co-occur in Royseux, from biostromal bafflestone to microbial-microconchid build-ups and limestone conglomerate. Several distinct micro-environments are therefore preserved and their faunal associations are quite distinct. Lateral facies variations are rather abrupt (see descriptions of the sections), but the fossiliferous facies occurs only in a much reduced area (a few hundred metres). This situation is uncommon in Viséan biostromes (cf. Aretz, 2010; Aretz et al., 2010) where facies are rather homogenous, but it is commonly observed in other types of reefs throughout geological history and, of course, in Recent reefs. A part of the biodiversity should be linked with the co-occurrence of micro-environments, but only a small number of facies yields corals at Royseux (Fig. 2): the Siphonodendron and Lithostrotion bafflestone, the bioclastic floatstone-rudstone (with and without gigantoproductines) and the conglomerate. The Saccaminopsis packstone, peloidal mudstone, microbialite and microconchid build-ups yield almost no corals. In contrast, the Gigantoproductus horizons are quite rich and diverse in rugose corals, which suggests that brachiopods and corals were not in competition and perhaps that corals took advantage of the water flows produced by the filtration systems of the brachiopods the same way that some scleractinian corals and giant clams interact in Recent reefs (Wood, 1999).

(2) Reworking and mixing. As highlighted by Aretz (2001), the conglomerate in parasequence +2 is composed of pebbles showing microfacies known from underlying strata (Fig. 3B), but also microfacies that are not known anywhere in the locality, suggesting of reworking and transportation from outside the outcrop area. Both coral and brachiopod diversity peak within the conglomerate (Table 1), but not only because of obviously reworked specimens. As explained above, many specimens seem to have lived within the pebbles as they do not show any trace of erosion that might be associated to reworking.

(3) Temporal bias. Most of the Royseux taxa were recorded from a single $4^{\text {th }}$ order parasequence $(100 \mathrm{kyr})$, and thus, in duration, the diversity is not likely to be related to a long term accumulation, such as those described from the Bristish Isles, Morocco or Spain (see section 5.1.).

(4) Palaeobiogeography. During the Late Viséan, global sea level was high, allowing easy connections and faunal exchange between various palaeogeographic areas, and thus resulting in many widely distributed and even cosmopolitan taxa (Fedorowski, 1981; Sando, 1990). The Namur-Dinant Basin was situated along the southern margin of Laurussia, flooded by the remnants of the Rhenohercynian Ocean and was separated from the Palaeotethys Ocean by Hunic Terranes (Armorica, French Central Massif, Saxo-thuringian and Moldanubian zones, the Turkish Anatolides, etc.; von Raumer et al., 2003). However, exchanges through this 'high' area were possible and marine faunas on both sides are quite similar (European Coral Province of Sando, 1990).

(5) Palaeoclimate. It is generally suggested that high temperatures (either in a greenhouse interval or during interglacials within icehouse intervals) are associated with high diversity (Cecca, 2002) and that high temperature is crucial for the establishment of new species (Berteaux et al., 2010). At global scales, the late Viséan was a time a high marine biodiversity (e.g. Raup \& Sepkowski, 1982; Wood, 2001; Kiessling, 2009). This peak is partly explained by tropical conditions prevailing on most of the Palaeotethys Ocean linked to high sea surface temperatures (Kiessling, 2009). The early Carboniferous climate was characterised by progressive cooling and the onset of the Late Palaeozoic Ice Age in the late Viséan (Isbell et al., 2003). However, sedimentary cycles related to glacio-eustatic sealevel changes have been reported from the Belgian platform sections as early as the early Viséan (Mottequin, 2008; Aretz et al., 2011). Similarly, the Middle Devonian and Late Cretaceous are dominated by third-order eustatic sequences that are most probably related to glacio-eustacy (see review by Miller et al., 2005). Both periods recorded warm conditions as proven by the wide carbonate platforms developed at high latitudes. Both periods are also associated with diversity peaks in the marine realm (Kiessling, 2009; Kiessling \& Kocsis, 2015).

\section{Conclusions}

Comparisons with other late Viséan fossiliferous sites indicate that the rugose coral fauna of Royseux is highly diverse, whether the entire stratigraphical section or particularly within parasequence +2 . However, the diversity of one taxonomic group may not be representative of another group (Price, 2002; Orme et al., 2005), and as such, Royseux is a biodiversity palaeo-hotspot for rugose corals but neither for tabulate corals nor brachiopods or other invertebrates (the latter are still poorly known and further studies could change this view). Outcrop conditions unfortunately preclude correct statistical sampling and in situ population study, such as those of Hubbard (1966) or Aretz (2002).

The origin of the high biodiversity cannot be explained by a single cause. Hence a complex network of global and local causes are necessary, but none of them seems to dominate. However, it is clear that the local influence of tectonics and lithofacies creating numerous micro-environments may explain why the diversity is restricted to a small area and not to the whole Namur-Dinant Basin.

Further comparison with other rich and better known coral sites in the Silurian (e.g. Gotland), Devonian (Ohio) or Cretaceous (Gossau) would possibly provide new insight into the causes of the diversity peak and what controlled the distribution of the other invertebrates.

\section{Acknowledgments}

The authors acknowledge Michael Amler for the pelecypod identifications. The authors are grateful to G. Sevastopoulo (Dublin) and G.E. Webb (Brisbane) for their constructive remarks on the manuscript and their help to improve the language. Joël Laval and the late Fernand Noebert are thanked for the preparation of the many thin sections.

\section{References}

Aretz, M., 2001. The upper Viséan coral-horizons of Royseux - The development of an unusual facies in Belgian Early Carboniferous. Tohoku University Museum, Bulletin, 1, 86-95.

Aretz, M., 2002. Habitatanalyse und Riffbildungspotential kolonialer rugoser Korallen im Unterkarbon (Mississippium) von Westeuropa. Kölner Forum für Geologie und Paläontologie, 10, 1-155.

Aretz, M., 2010. Habitats of colonial rugose corals: the Mississippian of western Europe as example for a general classification. Lethaia, 43, 558-572.

Aretz, M. \& Nudds, J., 2005. The coral fauna of the Holkerian/Asbian boundary stratotype section (Carboniferous) at Little Asby Scar (Cumbria, England) and implications for the boundary. Stratigraphy, 2/2, 167-190

Aretz, M., Denayer, J. \& Mottequin, B., 2013. Preliminary data on Viséan (Carboniferous) corals and brachiopods from the strata between the Djebel Begaa and the Gara El Itima (eastern Tafilalt, Morocco). Document de l'Institut scientifique de Rabat 27, 87-94.

Aretz, M., Herbig, H.G., Somerville, I. D. \& Cózar, P., 2010. Rugose coral biostromes in the late Viséan (Mississippian) of NW Ireland: Bioevents on an extensive carbonate platform. Palaeogeography, Palaeoclimatology, Palaeoecology, 292/3, 488-506.

Aretz, M., Chevalier, E., Poty, E. \& Chevalier, J., 2011. Cyclicity in the Middle Viséan strata of Belgium. In Hakansson, E. \& Trotter, J. (eds), Programme and abstracts: the XVII International Congress on the Carboniferous and Permian. Geological Survey of Western Australia, Record 2011/20, 41.

Barchy, L. \& Marion, J.-M., in press. Carte géologique de Wallonie: Modave-Clavier 48/7-8. 1/25.000. Namur, Ministère de la Région wallonne, Direction générale des ressources naturelles et de l'environnement, avec une notice explicative.

Bellwood, D.R., Wainwright, P.C., Fulton, C.J. \& Hoey, A.S., 2006. Functional versatility supports coral reef biodiversity. Proceedings of the Royal Society, 273, 101-107

Bellwood, D.R., Renema, W. \& Rosen, B.R., 2012. Biodiversity hotspots, evolution and coral reef biogeography. In: Gower, D.J., Johnson, K., Richardson, J., Rosen, B., Rüber, L. \& Williams, S. (eds). Biotic evolution and environmental change in Southeast Asia. Cambridge University Press, Cambridge, 216-245.

Berteaux, D., Blois, S.D., Angers, J.-F., Bonin, J., Casajus, N., Darveau, M., Fournier, F., Humphries, M.M., McGill, B., Larivée, J., Logan, T., Nantel, P., Périé, C., Poisson, F., Rodrigue, D., Rouleau, S., Siron, R., Thuiller, W. \& Vescovi, L., 2010. The CC-Bio project: studying 
the effects of climate change on Quebec biodiversity. Diversity, 2, 1181-1204.

Bowen, B.W., Rocha, L.A., Toonen, R.J., Karl, S.A. \& Tobo, L., 2013. The origins of tropical marine biodiversity. Trends in Ecology and Evolution, 28, 359-366.

Brown, J.H. \& Lomolino M.V., 2010. Biogeography (4th ed.). Sinauer Associates Publishers, Sunderland, $691 \mathrm{p}$.

Brunton, C.H.C., 1987. The palaeoecology of brachiopods, and other faunas, of Lower Carboniferous (Asbian) limestones in West Fermanagh. Irish Journal of Earth Sciences, 8, 97-112.

Brunton, C.H.C., Rachebœuf, P.R. \& Mundy, D.J.C., 1994. Reclassification of Semenewia concentrica (de Koninck, 1847) (Brachiopoda, Lower Carboniferous). Geobios, 27, 51-60.

Brunton, C.H.C. \& Tilsley, J.W., 1991. A checklist of brachiopods from Treak Cliff, Derbyshire, with reference to other Dinantian (Lower Carboniferous localities). Proceedings of the Yorkshire Geological Society, 48, 287-295.

Cecca, F., 2002. Palaeobiogeography of marine fossil invertebrates concepts and methods. Taylor \& Francis, London, 273 p.

Ciampaglio, C.N., 2002. Determining the role that ecological and developmental constraints play in controlling disparity: examples from the crinoid and blastozoan fossil record. Evolution and Development, 4, 170-188.

Cowman, P.F., Bellwood, D.R. \& Rocha, L.A., 2013. The historical biogeography of coral reef fishes: global patterns of origination and dispersal. Journal of biogeography, 40, 209-224.

de Koninck, L.G., 1842-1844. Description des animaux fossiles qui se trouvent dans le terrain carbonifère de Belgique. Dessain, Liège, 650 p.

de Koninck, L.G., 1847. Recherche sur les animaux fossiles. Première partie - Monographie des genres Productus et Chonetes. Dessain, Liège, $246 \mathrm{p}$.

de Koninck, L.G., 1887. Faune du calcaire carbonifère de la Belgique. Sixième partie. Brachiopodes. Annales du Musée d'Histoire naturelle de Belgique, 14, 1-154.

Delépine, G., 1928. Les Brachiopodes du Marbre noir de Dinant (Viséen inférieur). Mémoires du Musée royal d'Histoire naturelle de Belgique, 37, 1-39.

Demanet, F., 1934. Les brachiopodes du Dinantien de la Belgique. Vol. 1, Atremata, Neotremata, Protremata (pars). Mémoires du Musée royal d'Histoire naturelle de Belgique, 61, 1-116.

Demanet, F., 1958. Contribution à l'étude du Dinantien de la Belgique. Mémoires de 1'Institut royal des Sciences naturelles de Belgique 141, $1-152$.

Denayer, J., Poty, E. \& Aretz, M., 2011. Uppermost Devonian and Dinantian Rugose Corals from Southern Belgium and surrounding areas. In Aretz, M. \& Poty, E. (eds). 11th International Symposium on Fossil Cnidaria and Porifera - Liège, 19-29 August, 2011, FieldGuides; Kolner Forum für Geologie und Paläontologie, 20, 151-201.

Erwin, D.H., 1994. Early introduction of major morphological innovations. Acta Palaeontologica Polonica, 38, 281-294.

Erwin, D.H., 2007. Disparity: morphological pattern and developmental context. Palaeontology, 50, 57-73

Fedorowski, J., 1981. Carboniferous corals: distribution and sequence. Acta Palaeontologica Polonica, 26, 87-160.

Fulthorpe, C.S. \& Schlanger, S.O., 1989. Paleo-oceanographic and tectonic settings of early Miocene reefs and associated carbonates of offshore Southeast Asia. AAPG Bulletin, 73/6, 729-756.

Gould, S.J., 1988. Trends as changes in variance: a new slant on progress and directionality in evolution. Journal of Paleontology, 62, 319-329.

Gould, S.J., 1989. A developmental constraint in cerion, with comments on the definition and interpretation of constraint in evolution. Evolution, 43, 516-539.

Hance, L., Poty, E. \& Devuyst, F.-X., 2001. Stratigraphie séquentielle du Dinantien type (Belgique) et corrélation avec le Nord de la France (Boulonnais, Avesnois). Bulletin de la Société géologique de France, 172/4, 411-426

Hill, D., 1981. Rugosa and Tabulata. In Teichert, C. (ed.): Treatise on Invertebrate Paleontology, Part F, Coelenterata, Supplement 1., Geological Society of America, Boulder (Colorado) \& University of Kansas Press, Lawrence (Kansas), 762p .

Hubbard, J.A.E.B., 1966: Population studies in the Ballyshannon Limestone, Ballina Limestone, and Rhinn Oint Beds (Viséan). Palaeontology, 9, 252-269.

Hubbard, J.A.E.B., 1970. Sedimentological factors affecting the distribution and growth of Viséan caninioid corals in North-West Ireland. Palaeontology, 13/2, 191-209.

Hughes, T.P., Connoly, S.R. \& Keith, S.A., 2013. Geographic ranges of reef corals (Cnidaria: Anthozoa: Scleractinia) in the Indo-Pacific. Ecology, 94/7, 1659.

Isbell, J.L., Lenaker, P.A., Askin, R.A., Miller, M.F. \& Babcock, L.E., 2003. Reevaluation of the timing and extent of late Paleozoic glaciation in Gondwana: role of the Transantarctic Mountains. Geology, 31/11, 977-980.
Johnson, K.G., Hasibuan, F., Müller, W. \& Todd, J.A., 2015. Biotic and environmental origins of the southeast Asian marine biodiversity hotspot: the throughflow project. Palaios, 30, 1-6.

Karlson, R.H., Cornell, H.V. \& Hughes, T.P., 2004. Coral communities are regionally enriched along an oceanic biodiversity gradient. Nature, 429, 867-870.

Kiessling, W., 2009. Geologic and biologic controls on the evolution of reefs. Annual Review of Ecology, Evolution, and Systematics, 40, 173-192.

Kiessling, W. \& Kocsis, Á., 2015. Biodiversity dynamics and environmental occupancy of fossil azooxanthellate and zooxanthellate scleractinian corals. Palaeobiology, 41, 402-414.

Laloux, M., 1988. Foraminifères du Viséen supérieur et du Namurien du bassin franco-belge. In: Laloux, M., Bouckaert, J., Conil, R., Groessens, E., Laurent, S., Overlau, P., Pirlet, H., Poty, E., Schiltz, M. \& Vandenberghe, N. Pre-congress excursion to the Carboniferous stratotypes in Belgium. Bulletin de la Société belge de Géologie, 96/3, 205-220

Laurent, S., 1985. Contribution à l'étude litho- et biostratigraphique du Viséen supérieur de Royseux (Synclinorium de Dinant). Unpublished MSc thesis, University of Liège, $76 \mathrm{p}$.

Marchese, C., 2015. Biodiversity hotspots: A shortcut for a more complicated concept. Global Ecology and Conservation, 3, 297-309.

Merle D., 2008. Le Lutétien du bassin de Paris: un exemple de point chaud de la paléobiodiversité. In: Merle, D. (ed.). Stratotype Lutétien. MNHN/BRGM, Paris/Orléans, 174-181.

Miller, K.G., Kominz, M.A., Browning, J.V., Wright, J.D., Mountain, G.S., Katz, M.E., Sugarma, P.J., Cramer, B.S., Christie-Blick, N. \& Pekar, S.F., 2005. The Phanerozoic record of global sea-level change. Science, 310, 1293-1298

Mortelmans, G. \& Bourguignon, P., 1954. Le Dinantien. In : Fourmarier, P. (ed.). Prodrome d'une description géologique de la Belgique. Vaillant-Carmanne, Liège, 217-310.

Mottequin, B., 2008. The 'black marble' of Denée, a fossil conservation deposit from the Lower Carboniferous (Viséan) of southern Belgium. Geological Journal, 43, 197-208.

Mottequin, B., Poty, E., Prestianni, C., 2015a. Catalogue of the types and illustrated specimens recovered from the 'black marble' of Denée, a marine conservation-Lagerstätte from the Mississippian of southern Belgium. Geologica Belgica, 18, 1-14.

Mottequin, B., Sevastopulo, G. \& Simon, E., 2015b. Micromorph brachiopods from the late Asbian (Mississippian, Viséan) from northwest Ireland (Gleniff, County Sligo). Bulletin of Geosciences, 90, 307-330

Mottequin, B., Aretz, M., Herbig, H.-G., Baidder, L., Kaoukaya, A. \& Denayer, J., 2016 (in press). New insight on Carboniferous (Viséan) brachiopods from eastern Tafilalt (Morocco). Geological Journal, doi: $10.1002 /$ gj.2750.

Mottequin, B. \& Marion, J.-M., in press. Carte géologique de Wallonie : Huy - Nandrin 48/3-4. 1/ 25.000. Namur, Ministère de la Région wallonne, Direction générale des ressources naturelles et de l'environnement, avec une notice explicative.

Muir-Wood, H. \& Cooper, G.A., 1960. Morphology, classification and life habits of the Productoidea (Brachiopoda). The Geological Society of America, Memoir, 81, 1-447.

Mundy, D.J.C., 1994. Microbialite-sponge-bryozoan-coral framestones in Lower Carboniferous (Late Visean) buildups of nothern England (UK). In: Embry, A.F., Beauchamp, B. \& Glass, D.J., (eds). Pangea: global environments and resources. Canadian Society of Petroleum Geologists Memoir, 17, 713-729.

Myers, N., 1988. Threatened biotas: "Hotspots" in tropical forests. Environmentalist, 8, 1-20.

Myers, N., Mittermeier, R.A., Mittermeier, C.G., da Fonseca, G.A. \& Kent, J., 2000. Biodiversity hotspots for conservation priorities. Nature 403, 853-858.

Oliver, W.A., Jr., 1992. Corals form the Turkey Creek Limestone (Lower Devonian), Southern Oklahoma. Oklahoma Geological Survey Bulletin, 145, 137-159.

Orme, C.D.L., Davies, R.G., Burgess, M., Eigenbrod, F., Pickup, N., Olsen, V.A., Webster, A.J., Ding, T.-S., Rasmussen, P.C., Ridgely, R.S., Stattersfield, A.J., Bennett, P.M., Blackburn, T.M., Gaston, K.J. \& Owens, I.P.F., 2005. Global hotspots of species richness are not congruent with endemism or threat. Nature, 436, 1016-1019

Pirlet, H., 1968. La sédimentation rythmique et la stratigraphie du Viséen supérieur V3b, V3c inférieur dans les synclinoriums de Namur et de Dinant. Académie royale de Belgique, Mémoires in $4^{\circ}$ de la classe des Sciences, 2ème série, 17/4, 1-98.

Plaisance, L., Caley, M.J., Brainard, R.E. \& Knowlton, N., 2011. The diversity of coral reefs: What are we missing? PLoS ONE 6/10, e25026.

Potts, D.C., 1983. Evolutionary disequilibrium among Indo-Pacific corals. Bulletin of Marine Science, 33/3, 619-632. 
Poty, E., 1981. Recherches sur les Tétracoralliaires et les Hétérocoralliaires du Viséen de la Belgique. Mededelingen Rijks Geologische Dienst, $35 / 1,1-161$

Poty, E., Hance, L., Lees, A. \& Hennebert, M., 2001. Dinantian lithostratigraphic units (Belgium). Geologica Belgica, 4/1-2, 69-94.

Poty, E., Devuyst, F.-X. \& Hance, L., 2006. Upper Devonian and Mississippian foraminiferal and rugose coral zonations of Belgium and Northern France, a tool for Eurasian correlations. Geological Magazine, 143/6, 829-857.

Poty, E., Conil, R., Groessens, E., Laloux, M. \& Laurent, S., 1988. Royseux. In: Laloux, M., Bouckaert, J., Conil, R., Groessens, E., Laurent, S., Overlau, P., Pirlet, H., Poty, E., Schlitz, M. \& Vanguestaine, M., Pre-congress excursion to the Carboniferous stratotypes in Belgium. Bulletin de la Société belge de Géologie, 96/3, 243-247.

Poty, E., Aretz, M. \& Denayer, J., 2011. Field trip 3: Uppermost Devonian and Lower Carboniferous of Southern Belgium. In Aretz, M. \& Poty, E. (eds). 11th International Symposium on Fossil Cnidaria and Porifera - Liège, 19-29 August, 2011, Field-Guides; Kolner Forum für Geologie und Paläontologie, 20, 99-150.

Price, A.R.G., 2002. Simultaneous 'hotspots' and 'coldspots' of marine biodiversity and implications for global conservation. Marine Ecology Progress Series, 241, 23-27.

Reaka, M.L. \& Lombardi, S.A., 2011. Hotspots on global coral reefs. In: Zachos, F.E. \& Habel, J.C. (eds). Biodiversity hotspots: distribution and protection of conservation priority areas. Springer, Berlin, 471-501.

Reaka, M.L., Rodgers, P.J. \& Kudla, A.U., 2008. Patterns of biodiversity and endemism on Indo-West Pacific coral reefs. Proceedings of the National Academy of Sciences, 105, 11474-11481.

Renema, W., Bellwood, D.R., Braga, J.C., Bromfield, K., Hall, R., Johnson, K.G., Lunt, P., Meyer, C.P., McMonagle, L.B., Morley R.J., O'Dea, A., Todd, A., Wesselingh, F.P., Wilson, M.E.J. \& Pandolfi, J.M., 2008. Hopping hotspots: global shifts in marine biodiversity. Science, 321, 654-657.

Raup, D.M., \& Sepkowski, J.J., Jr., 1982. Mass extinctions in the marine fossil record. Science, 215, 1501-1503.

Rodríguez, S., Somerville, I. D., Said, I., \& Cózar, P., 2012. Late Viséan coral fringing reef at Tiouinine (Morocco): implications for the role of rugose corals as building organisms in the Mississippian. Geological Journal, 47/5, 462-476.

Rodríguez, S., Somerville, I. D., Cózar, P., Coronado, I. \& Said, I., 2016 (in press). Inventory and analysis of the distribution of Viséan corals from the Guadiato Area (Córdoba, SW Spain). Spanish Journal of Palaeontology.

Rosen, B.R., 1988. Progress, problems and patterns in the biogeography of reef corals and other tropical marine organisms. Helgoländer Meersuntersuchungen, 42, 269-301.

Said, I., Rodríguez, S., Somerville, I.D. \& Cózar, P., 2011. Environmental study of coral assemblages from the upper Viséan Tizra Formation (Adarouch area, Morocco): implications for Western Palaeotethys biogeography. Neues Jahrbuch für Geologie und Paläontologie, 260/1, 101-118.

Said, I., Somerville, I., Rodríguez, S. \& Cózar, P., 2013. Mississippian coral assemblage from the Khenifra area, central Morocco: biostratigraphy, biofacies, palaeoecology and palaeobiogeography. Gondwana Research, 23, 367-379.

Sando, W.J., 1990. Global Mississippian coral zonation. Courier Forschungsinstitut Senckenberg, 130, 173-187.

Stampfli, G. \& Borel, G.D., 2002. A plate tectonic model for the Paleozoic and Mesozoic constrained by dynamic plate boundaries and restored synthetic ocean isochrons. Earth and Planetary Science Letters, 196, 17-33.

Veron, J.E.N., 2000. Corals of the world. Australian Institute of Marine Science, Townsville, Australia, 463p. (vol. 1), 429p. (vol. 2), 490p. (vol. 3).

von Raumer, J.F., Stampfli, G. \& Bussy, F., 2003. Gondwana-derived microcontinents - the constituents of the Varsican and Alpine collisional orogens. Tectonophysics, 365, 7-22.

Waters, J. \& Webster, G.D., 2012. The paleobiogeography of Pennsylvanian crinoids and blastoids. In: Talent, J. (ed.). Earth and Life. Springer, Dordrecht, 831-847.

Webb, G.E., 1987. Late Mississippian thrombolite bioherms from the Pitkin Formation of northern Arkansas. Geological Society of America Bulletin, 99/5, 686-698.

Webb, G.E., 1990. Lower Carboniferous coral fauna of the Rockhampton Group, East-Central Queensland. Memoirs of the Association of Australasian Palaeontologists, 10, 1-167.

Webb, G.E., Sando, W.J. \& Raymond, A., 1997. Mississippian coral latitudinal diversity gradients (western interior United States): testing the limits of high resolution diversity data. Journal of Paleontology, 71, 780-791.
Williams, S.T. \& Duda, T.F., 2008. Did tectonic activity stimulate OligoMiocene speciation in the Indo-West Pacific? Evolution, International Journal of Organic Evolution, 62, 1618-1634.

Wilson, M.E. \& Rosen, B.R., 1998. Implications of paucity of corals in the Paleogene of SE Asia: plate tectonics or centre of origin. In: Hall R. \& Holloway J.D. (eds). Biogeography and geological evolution of SE Asia. Backhuys publishers, Leiden, 165-195.

Whittaker, R.H., 1972. Evolution and measurement of species diversity. Taxon, 21, 213-251.

Wood, R., 1999. Reef evolution. Oxford University Press, Oxford, 414p.

Wood, R., 2001. Biodiversity and the history of reefs. Geological Journal, 36/3-4, 251-263.
Manuscript received 27.11.2015, accepted in revised form 23.01.2016, available on line 19.02.2016. 